\title{
A METHOD FOR MEASUREMENT OF TERRESTRIAL HEAT FLOW DENSITY IN WATER WELLS
}

\author{
JANILO SANTOS \\ Grupo de Geofisica - Deparcamento de Física - UFRN \\ C.P. 143 - 59000 - Nakal, RN, Brazil \\ VALIYA M. HAMZA \\ Instituro de Pesquisas Tecnologicas - IPT \\ Cidade Universitínia - 05508 - Sāo Paulo, SP - Brazil \\ PO-YU SHEN \\ Department of Geophysics, Uwo, London - Canade
}

A simple method for maasurement of terrestrial heat flow density in wells drawing groundwoter from confined aquifers is presented. It requires laboratory determination of thermal resistance but the field work is simple, being limited to measu rement of temperature of water at the well mouth during pumping tests.

The aquifer temperature (Ta) is calculated from the measu red temperature at the well mouth (TW), the mass flow rate $(M)$ and the depth to the top of the aqui fer $(H)$ using the relation

$$
(T w-T o) /(T a-T o)=M^{\prime} R\left[1-\exp \left(-1 / M^{\prime} R\right)\right]
$$

where To is the mean annual surface temperature, $R$ a dimensionless diffusion parameter and $M^{r}$ $=M C / K H$ is the dimensionless mass flow rate, $C$ being the specific heat of water and $K$ the thermal conductivity of the rock fo mation penetrated by the well. The heat flow density (q) is then calculated from the relation

$$
q=(T a-T o) / \sum_{i=1}^{n} P_{i} Z_{i}
$$

where $P_{i}$ is the thermal resistivity of the th layer of thickness $Z_{i}$ and $n$ the number of layers. The procedure also allow corrections for the influence of thermal conductivity variations of the wall rooks.

This method was used for the determination of heat flow density values for thiteen sites in the northeastem part of the Paraná basin. The mean value obtained is $62 \pm 4 \mathrm{~mW} / \mathrm{m}^{2}$ in good agreement with the mean of $59 \pm 9 \mathrm{~mW} / \mathrm{m}^{2}$ obtained by the conventional method for thitteen sites in the Parana basin. Though similar in principle to the bottom-hole temperature method used in oil wells, the present technique has some inherent advantages. It is potentially capable of providing a wider gecographic representation of heat flow density (bei ngnot limited to peroleum fields) and is relati vely freeof the sampling problems nomally encountered in working with oil companies. On the other hand the present method may provide unreliable values in the case of wells draving water from more than one aquifer.

Apresenta-se neste trabalho, um método simples para a deteminacāo do fluxo geotérmico em posos em atividade de bombeamento de água subterrânea. O método requer a determinaçáo em laboratório da resisténcia témica total das camadas atravessadas pelo poco mas, o trabalho de campo é simples, limitando-se à medida da temperatura da água na boca do poço du rante ensaios de bombeamento. 
A temperatura do aquífero $\left(T_{a}\right.$ ) é calculada a partir da temperatura da água ( $T_{W}$ ) medida na boca do poço da vazăo (M) expressa errimassa de água produzida pelo popo por unidade de tempo e, da profundidade do topo do aquífero $(H)$ usando-se a relaçầ

$$
(T w-T o) /(T a-T o)=M^{\prime} R\left[1-\exp \left(-1 / M^{\prime} R\right)\right]
$$

onde $T_{0}$ é a temperatura média anual da superficie, $R$ é um paràmetro adimensional de difusấ, $M^{\prime}=M C / K H$ é a vazào adimensional do poço, C éo calor especifico da água e, $K$ é a condutividade térmica da rocha atravessada pelo pogo. O fluxo geotérmico $(\mathrm{q}$ \} é calculado pela relaçāo

$$
q=(T a-T o) / \sum_{i=1}^{n} p_{j} Z_{i}
$$

onde Pi é a resistência témica da i-ésima camada de espessura Zi e, n é o número de camadas.

O método pemite também a introduçāo de correçōes da influência das variaçōes de condutividade térmica das paredes do poşo.

Este método foi utilizado na démina a a do fluxo gootémico em treze localidades no no rdeste da Bacia do Paraná. $O$ valor médio obtido foi de $62 \pm 4 \mathrm{~mW} / \mathrm{m}^{2}$, concordando com o valor médio de $59 \pm 9 \mathrm{~mW} / \mathrm{m}^{2}$ obtido pelo método convencional de deteminação de fluxo geotérmico em treze localidades da Bacia do Paraná. Apesar de ser um método similar a des temperaturas de fundo de poço usado em poços de petróleo, esta técrica apresenta algumas vantagens. O método é potencialmente capaz de fo mecer uma representaça geográfica mais ampla do fluxo geotenmic, não estando limitado a campos de produção de petról mas de amostragem nomalmente encontrados quando se trabalha com companhias de petróleo. Por outro lado, este método pode fo mecer valores irreais de fluxo geotémnico no caso em queo poço extraia água de mais de um aquífero.

\section{INTRODUCTION}

Measurements of terrestrial heat flow density in continental regions have lagged considerably behind those in oceanic regions mainly because of the difficulty in finding suitable deep boreholes, wells, mines or tunnels for geothermal studies In developing countries, lack of adequate temperature logging equipments also contribute to the difficulties in making use of conventional methods of high quality terrestrial heat flow density determinations. Thus a necessity exists for divising simpler methods.

Carvalho \& Vacquier (1977) and Evans (1977) suggested a method suitable for determination of heat flow in oil wells without the necessity of making detailed temperature logs. It makes use of bottom hole temperature measurements made by oil companies and determinations of thermal conductivity of major rock formations in the laboratory. Unfortunately, use of this method is $\mathrm{ij}-$ mited to petroleum bearing fields in sedimentary basins. Another problem with this method is the necessity of having to make a large number of thermal conductivity measurements to obtain a representative value of the cumulative thermal resistance. Evans (1977) suggested the possibility of making use of empirical reburos ting thermal conductivity with such parametzes velocity, bulk density and porosity, determined ventional geophrsical log data. Howevers stedt

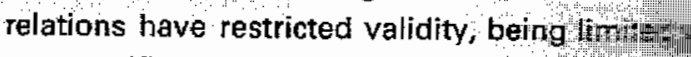
one specific oil field.

Swanberg \& Morgan (1978) propossade th for determining heat flow density when $\mathrm{a}$, cally significant body of geochemical data $3^{2}$ / thet for a regionally representative set of thermedir shy modified version of this method was sugges (1984) incorporating mass flow data for the the det A sumary of the principal methods used 4 int measurements is given in Table $(1)$.

\section{A METHOD FOR HEAT FLOW MEASU WATER WELLS}

Water wells are more abundant $x$ than oil wells. Hence, a method sultab-s

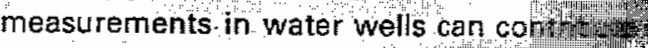

to overcoming the problerm thet many continental regions. Conventurt 
Summary of Principal Methods used for terrestrial heat flow density determinations.

\begin{tabular}{|c|c|c|c|}
\hline Method & ${ }_{1}$ & 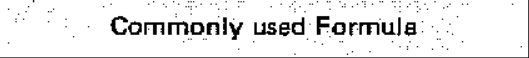 & nce \\
\hline $\begin{array}{l}\text { CONVENTIONAL } \\
\text { COMULATIVE } \\
\text { THERMAL } \\
\text { RESISTANCE } \\
\text { BOTTOM HOLE } \\
\text { GEOCHEMICAL- } \\
\text { STATISTICAL } \\
\text { GEOCHEMICAL } \\
\text { MASS FLOW } \\
\qquad\end{array}$ & $\begin{array}{l}\text { For thick homogeneous layers of } \\
\text { constant thermal conductivity } \\
\text { For alternating sequences of thin } \\
\text { layers with substantial thermal } \\
\text { conductivity contrasts. } \\
\text { For use in oil wells with only } \\
\text { Bottom hole temperatures. } \\
\text { Use for a group of thermal } \\
\text { springs with silica temperature } \\
\text { data. } \\
\text { Used for a single or a group of } \\
\text { springs with any geochemical } \\
\text { thermometer data and flow } \\
\text { rate estimates. } \\
\text { For use in water wells. } \\
\text { (For detaits see text), } \\
\text { F }\end{array}$ & 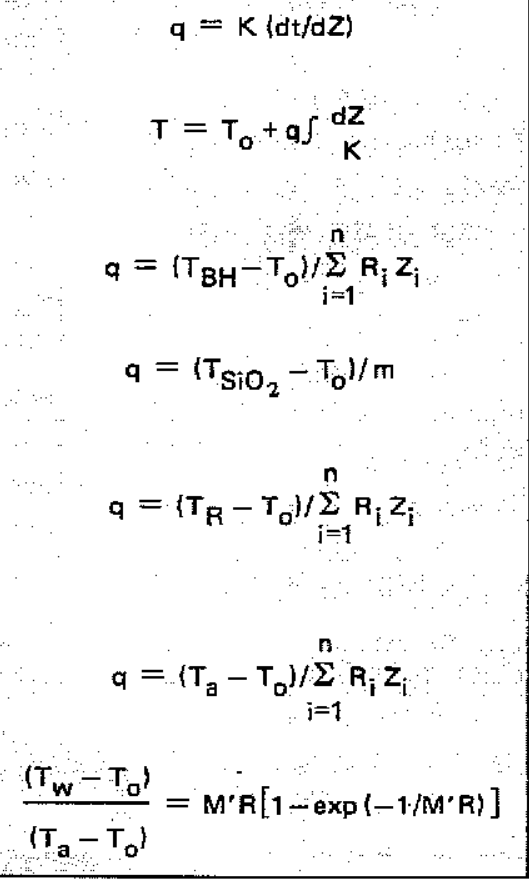 & $\begin{array}{lll}\text { Hurter (1984) } \\
\text { Present Work } \\
\therefore \quad\end{array}$ \\
\hline
\end{tabular}

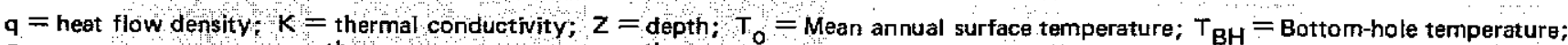
$R_{i}=$ thermal resistivity of 1 th layer; $Z_{i}=$ thickness of 1 th layer; $N=$ number of layers; $T_{\text {siO }}=$ Silica temperature; $m=$ a constant equal to $680\left({ }^{\circ} \mathrm{C} \mathrm{m}^{2} / \mathrm{W}\right) ; \mathrm{T}_{\mathbf{R}}=$ reservoir temperature using any geochernical thermometer; $T_{\mathrm{w}}=$ well mouth temperature; $\mathrm{M}=$ dimensionless mass-flow rate; $R=$ Dimensionless parameter; $T_{a}=$ Aquifer temperature.

ving temperature logging for the determination of thermal gradientes in water wells have proved to be unsuitable because of the marked effect of groundwater circulation on the sub-surface temperature distribution. Mansure and Reiter (1979), based on earlier works of Stallman (1960) and Bredehoeft and Papadopulos (1965), have outlined a method for correcting heat flow measurements in the presence of slow vertical gound water movements in the formation. In many cases however, the magnitudes of alterations in the thermal regime induzed by groundwater flow are such that it is difficult to make such corrections.

On the other hand it is possible to determine heat flow density if the hydrological disturbance is limited to the layers above the aquifer. Deep seated confined aquifers usually satisfy this condition due to the fact that they overlay impermeable substrata. Away from zones of active recharge or discharge the natural leakage rates of confined aquifers are small compared to the quantity that is stored. consequently the thermal inertia of aquifers are substantially higher than those of the confining layers and they act as cushions against hydrologically induzed thermal perturbations, In such cases the relation between aquifer temprature (Ta) and the background heat flux $(q)$ is given by

$$
T_{a}=T_{0}+\int_{0}^{Z} q P(Z) d Z
$$

where $\mathrm{Ta}$ is the aquifer temperature, To is the mean annual surface temperature, $q$ is the terrestrial heat flow density and $P(Z)$ is the thermal resistivity at depth $z$. In the absence of heat losses or gains, $q$ is a constant, given by

$$
q=(T a-T o) / \int_{0}^{Z} P(Z) d Z
$$

In the homogeneous, constant property multilayer case the integral in equation (2) can be replaced by the sum $\sum_{j=1}^{n} P_{i} Z_{j}$, where $P_{i}$ is the thermal resistivity of the layer with thickness $Z_{i}$ and $n$ is the number of layers. Equation (2) is independent of the form of temperature distribution in layers above the aquifer and can be used for calculating a as long as Ta itself is unaffected by water movements 


\section{DETERMINATION OF AOUIFER TEMPERATURE}

The aquifer temperature (Ta) can be determined from temperature logs in thermally stabilized wells. This is however not always practical due to the presence of pumping equipments in wells. In such cases it is possible to abtain a fairly good estimate of $T a$ by making temperature measurements of water at the well mouth during pumping tests. If the flow rate is relatively high the temperature of water at the well mouth (Tw) is nearly equal to the aquifer temperature (Ta). In case of low flow rates one may make use of the relation given by Bolditzsar (1958) for correcting for the effects of radial heat losses:

$$
(T w-T o) /(T a-T o)=M^{\prime} R\left[1-\exp \left(-1 / M^{\prime} R\right)\right]
$$

$M^{\prime}=M C / K H$ is the dimensionless mass flow rate $I M$ is the mass flow rate of water during pumping tests, $C$ is the specific heat of water, $K$ is the average thermal conductivity of the rock formations through which the well passes, $H$ the depth to the top of the aquifer) and $R$ is a parameter given by (Birch, 1947):

$$
R=\underset{\left(r^{2} / 4 k t\right)}{(1 / 4 \pi) \int^{\alpha} Z^{-1} \exp (-Z) \operatorname{lo}(Z) d Z}
$$

where $r$ is the radius of the well, $k$ is the thermal diffusivity of the rock formation, $t$ the time since pumping starts and lo the modified Bessel function of the first kind of order zero. The value of $R$ as a function of $Y=\left(4 \mathrm{kt} / \mathrm{r}^{2}\right)$ is shown in Fig. 1. For large values of time, i.e.: for wells which have been in use continuously for several years, the value of $R$ approaches a value of about $2 / \pi$ and is rather insensitive to small changes in " $t$ ". However it is necessary to caution here that wells which have been in use for several years may have induced long term changes in the aquifer temperature itself and thus may not be suitable for the determination of "steady state" heat flow density values.

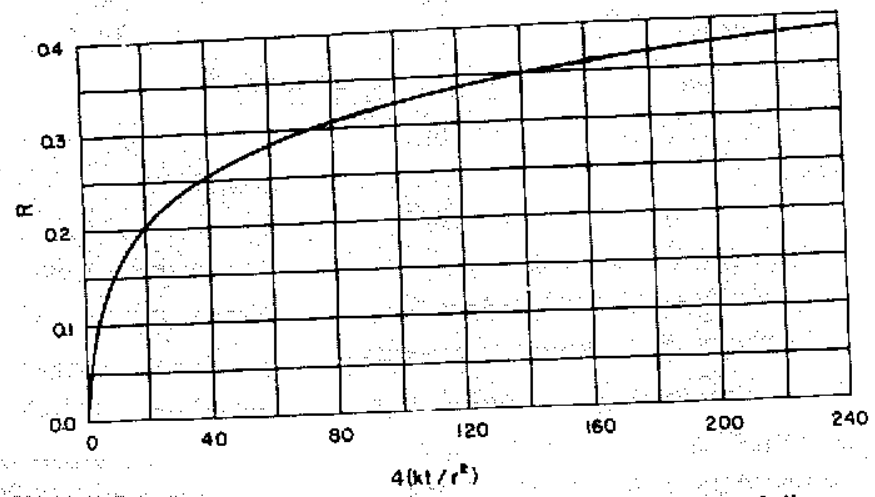

Figure 1 - Variation of the parameter $R$ as a function of dimensonless time $Y=4 \mathrm{kt} / \mathrm{r}^{2}$. For explanation of symbols see text.
The variation of the temperature $\mathrm{r}$ (Tw-To)/(Ta-To) with the mass flow rate $M$ for sey depths $H$ is plotted in figure 2 for $R=0.244$. This valu $R$ corresponds to a time of 24 hours after pumping $s t$ in a well of $20 \mathrm{~cm}$ diameter and with a wall rock the diffusivity of $0.01 \mathrm{~cm}^{2} / \mathrm{s}$. As can be easily noted from type curves in Fig. 2 the correction factor beco significant only for deep welis $(H>1000 \mathrm{~m})$ with very flow rates $(M<10 \mathrm{~kg} / \mathrm{s})$. Fig. 3 shows the variatio (Tw-To)/(Ta-To) with $M$ for the long term case of $2 / \pi$ (Truesdell et al., 1977) and again the corres factor becomes large only at unreasonably low flow A comparison of Figs. 2 and 3 point out the impo fact that at flow rates in excess of $50 \mathrm{~m}^{3} / \mathrm{h}$ the corre factor is rather insensitive to small changes in the val $R$. Variations in other parameters may produce signin errors in the correction factor and it is worth exam this aspect of the problem in a little more detail.

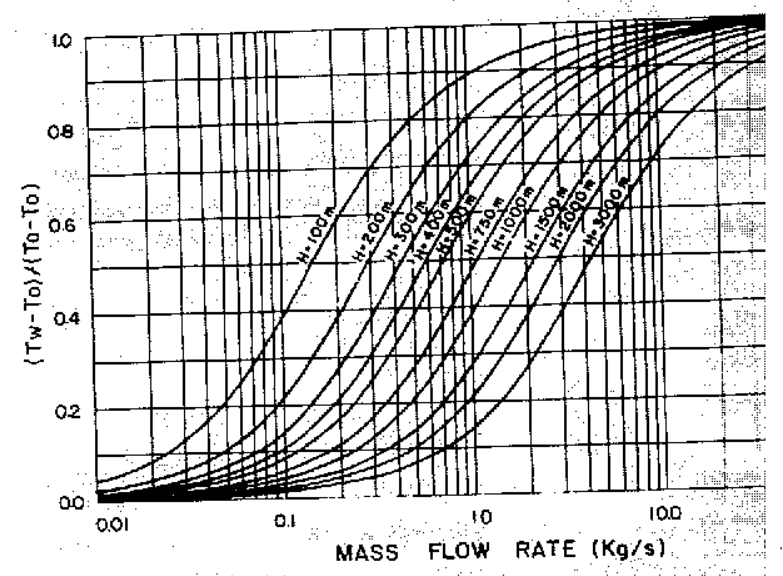

Figure 2 - Type cunves demonstrating the relation bet correction factor ( $T w-T o) /(T a-T o)$ and the $T$ rate for the short term case of $R=0.244 a$ veral different aquifer depths $\{H\}$.

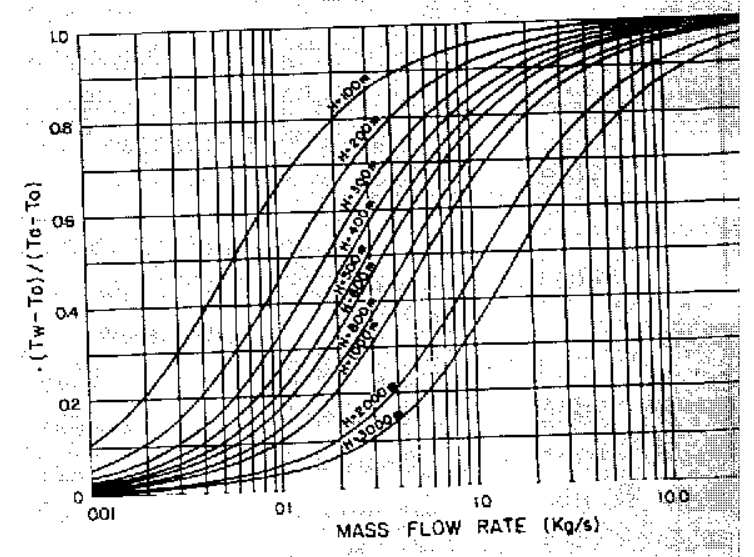

Figure 3 - Type curves demonstrating the relaton 0 correction factor (Tw-Tol/(Ta-To) and the rate for the long term case of $R=2 / \pi \mathrm{a}^{-2}$ different aquifer depths $(\mathrm{H})$; 


\section{DETERMINATION OF AQUIFER TEMPERATURE}

The aquifer temperature ( $\mathrm{Ta}$ ) can be determined from temperature logs in thermally stabilized wells. This is however not always practical due to the presence of pumping equipments in wells. In such cases it is possible to obtain a fairly good estimate of $\mathrm{Ta}$ by making temperature measurements of water at the well mouth during pumping tests. If the flow rate is relatively high the temperature of water at the well mouth (TW) is nearly equal to the aquifer temperature ( $T$ a). In case of low flow rates one may make use of the relation given by Bolditzsar (1958) for correcting for the effects of radial heat losses:

$$
(T w-T o) /(T a-T o)=M^{\prime} R\left[1-\exp \left(-1 / M^{\prime} R\right)\right]
$$

$M^{\prime}=M C / K H$ is the dimensionless mass flow rate $(M$ is the mass flow rate of water during pumping tests, $C$ is the specific heat of water, $K$ is the average thermal conductivity of the rock formations through which the well passes, $H$ the depth to the top of the aquifer) and $R$ is a parameter given by (Birch, 1947):

$$
R=\underset{\left(r^{2} / 4 k t\right)}{(1 / 4 \pi) \int^{\alpha} Z^{-1} \exp (-Z) l o(Z) d Z}
$$

where $r$ is the radius of the well, $k$ is the thermal diffusivity of the rock formation, $t$ the time since pumping starts and to the modified Bessel function of the first kind of order zero. The value of $R$ as a function of $Y=\left(4 \mathrm{kt} / \mathrm{T}^{2}\right\}$ is shown in fig. 1. For large values of time, i.e.: for wells which have been in use continuously for several years, the value of $R$ approaches a value of about $2 / \pi$ and is rather insensitive to small changes in " $t$ ". However it is necessary to caution here that wells which have been in use for several years may have induced long term changes in the aquifer temperature itself and thus may not be suitable for the determination of "steady state" heat flow density values.

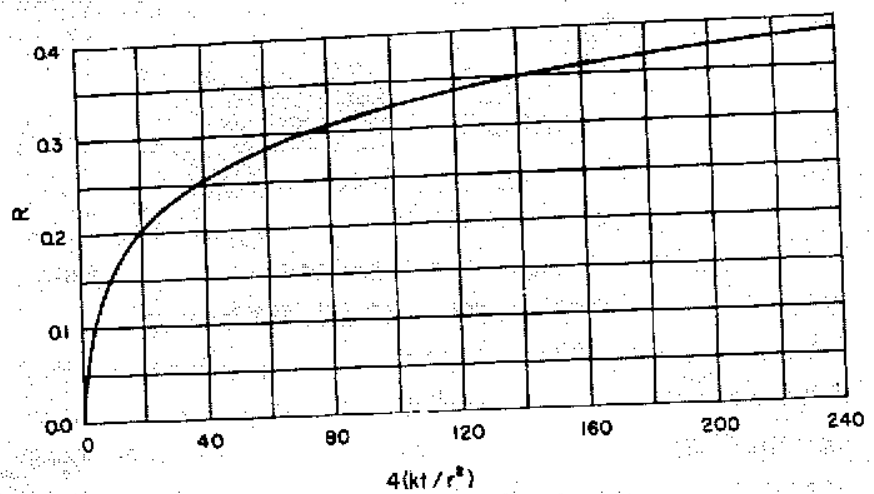

Figure 1 - Variation of the parameter $R$ as a function of dimensionless time $Y=4 k t / r^{2}$. For explanation of symbols see text.
The variation of the temperature (Tw-To)/ Ta-To) with the mass flow rate $M$ for sev depths $H$ is plotted in figure 2 for $R=0.244$. This valu $R$ corresponds to a time of 24 hours after pumping $s t$ in a well of $20 \mathrm{~cm}$ diameter and with a wall rock ther diffusivity of $0.01 \mathrm{~cm} 2 / \mathrm{s}$. As can be easily noted from type curves in Fig 2 the correction factor becol significant only for deep wells $(H>1000 \mathrm{~m})$ with very flow rates $(M<10 \mathrm{~kg} / \mathrm{s})$. Fig. 3 shows the variatiol (Tw-Tol/ Ta-To) with $M$ for the long term case of $2 / \pi$ (Truesdell et al., 1977) and again the correc factor becomes large only at unreasonably low flown A comparison of Figs. 2 and 3 point out the impo fact that at flow rates in excess of $50 \mathrm{~m}^{3} / \mathrm{h}$ the corre factor is rather insensitive to small changes in the val R. Variations in other parameters may produce signil errors in the correction factor and it is worth exam this aspect of the problem in a little more detail.

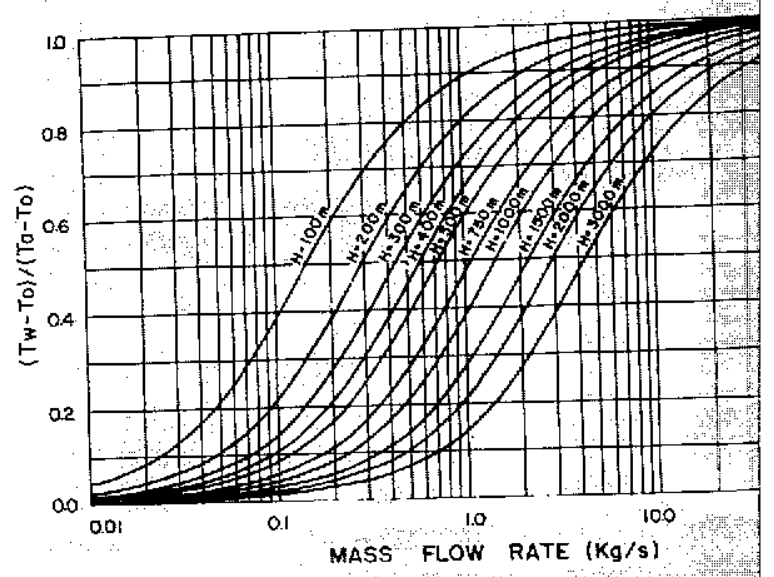

2 - Type curves demonstrating the relation bet correction factor (Tw-To)/(Ta-To) and the $\mathrm{t}$ ) rate for the short term case of $\mathrm{R}=0.244$ a veral different aquifer depths $(H)$.

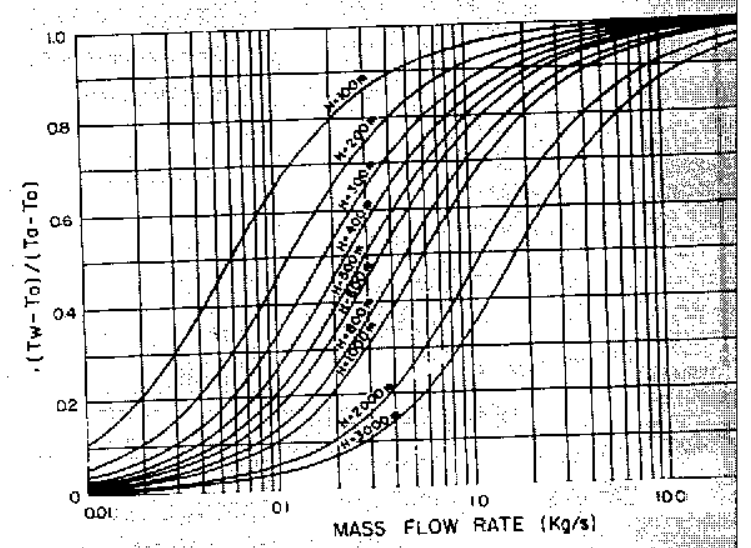

Figure 3 - Type curves demonstrating the relation correction factor (Tw-To)/(Ta-To) and the rate for the long term case of $\mathrm{R}=2 / \pi \mathrm{trl}$ different aquifer depths $(H)$. 
Usually in the case of water wells the flow rate (M) and depth to the top of the main aquifer (H) are known but the mean thermal conductivity may vary from one well to another. Hence it is sometimes more convenient to relate dimensionless temperature in equation (3) to a dimensionless conductivity parameter $(x)$ given by:

$$
x=(R)(C M / H)(1 / K)
$$

and hence

$$
\left(T w-T_{0}\right) /(T a-T o)=x[1-\exp (-1 / x)]
$$

Variation of dimensionless temperature as a function of $x$ is shown in figure 4 (continuous line) while the relation between $x$ and thermal conductivity $(K)$ of the wall rocks is shown by datted lines in the same figure for various values of $A=(2 / \pi)(\mathrm{CM} / \mathrm{H})$. Thus laboratory measurements of thermal conductivity can be used in combination with the value of A evaluated from well data to determine the correction factor (Tw-Tol/(Ta-To). As an illustrative example consider a well intersecting an aquifer at a depth of 266 meters and being pumped at the rate of $0.36 \mathrm{~m}^{3} / \mathrm{h}$. In this case $A=1$ and the thermal conductivity is $4 \mathrm{~W} / \mathrm{mOC}$ the correction factor is 0.25 (stipled line - I Fig.4). If now the pumping rate is increased to $3.6 \mathrm{~m}^{3} / \mathrm{h}$ the value of $\mathrm{A}$ is 10 and the correction factor is 0.82 (stipled line II in Fig. 4). Stipled line III refer to the case in which the pumping rate is $3.6 \mathrm{~m}^{3} / \mathrm{h}$ while the mean thermal conductivity is only $2 \mathrm{~W} / \mathrm{m}$ OC. In this latter case the correction factor is 0.91 . These results show that for shallow wells with flow rates in excess of $20 \mathrm{~m}^{3} / \mathrm{h}$ normal variations in thermal conductivities have very little effect on the correction factor. Usually pumping tests of water wells are carried out in steps of increasing flow rates in order to evaluate the hydrological characteristics of the aquifer. Obviously tempratures measured at different flow rates will be of considerable help in determining the correction factor more accurately.

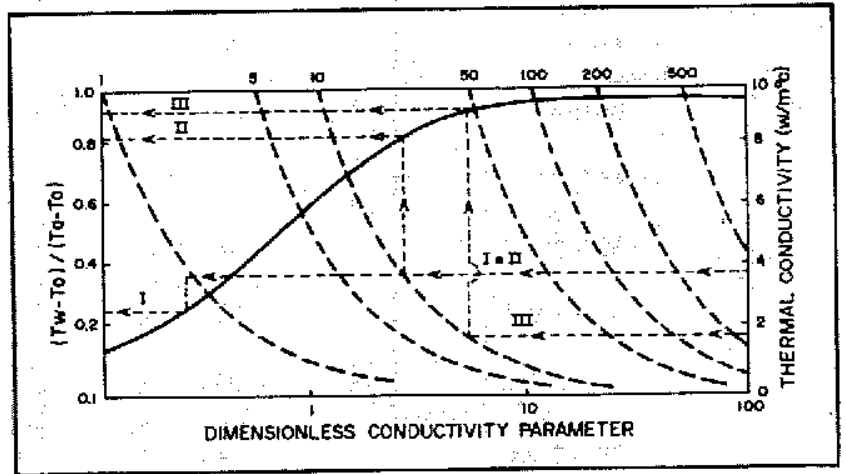

Figure 4 - Dependance of ine correction factor on the dimensionless conductivity parameter (the continuous line) and the thermal conductivity of wall rocks (dashed lines). The numbers above the dashed lines refer to values of the parameter $A$. For explanation of stipled lines see text.

\section{THERMAL CONDUCTIVITY MEASUREMENTS}

Samples available from water wells for thermal conductivity measurements are usually in the from of chips and powder because of the drilling techniques (percussion and rotary) commonly employed. The cell technique used by Sass et al. (1971) can be adapted for the determination of thermal conductivity of the solid matrix from laboratory measurements on water saturated samples. The effect of porosity on thermal conductivity is however more difficult to evaluate in certain cases as porosity logs are not normally carried out as a standard procedure in water wells. One possible way to overcome this problem is to make use of substandards of known porosity, pulverized into a form similar to that of the sample. If the sample porosity is not very different from that of the substandard, errors in the conductivity values can be kept to a minimum.

\section{APPLICATION OF THE METHOD}

Several deep wells drilled for groundwater in the north-eastern portion of the Parana basin, shown in Fig. 5 , offered an opportunity to test the usefulness of this method against other methods of determining terrestrial heat flow density of the western part of São Paulo state. The main aquifer in this region is the Botucatu Sandstone formation confined between the relatively impermeably paleozoic sedimentary rocks at the bottom and tholeitic flood basalts of the Serra Geral formation at the top. Temperature measurements were carried out during pumping tests by the Departamento de Água e Energia Elétrica - (DAEE, 1981), in thirteen wells using standard mercury thermometers. In some wells measurements were made by Instituto de Pesquisas Tecnológicas (IPT) using high precision thermistor thermometers. The mean annual surface temperature values were taken from the

climatological data of Pereira (1969). The field temperature data for the thirteen wells in the western parts of the state of São Paulo are given in Table 3. Several hundred measurements of thermal conductivity were carried out on samples from several wells. Measurements were carried out on samples of chips and powder using a dividedbar apparatus. The divided-bar is calibrated using substandards crushed in to the form of chips. Because most of the sample were basalts we used fine grained basalt as substandard. The water saturated thermal conductivity of solid basalt was determined by the divided-bar method making use of fused silica discs as primary standards.

The results of thermal conductivity measurements are presented in Table 2 and have been useful in the construction of generalized thermal resistivity profiles of the 
upper rock formations in the northeastern parts of the Parana basin.

Table 2 Thermal conductivities of principal rock types in the upper formations in the northeastern parts of the $\mathrm{Pa}$ rana basin.

\begin{tabular}{|c|c|c|c|}
\hline Formation & Rock Type & $\begin{array}{c}\text { Number } \\
\text { of } \\
\text { Analysis }\end{array}$ & $\begin{array}{c}\text { Thermal } \\
\text { Conductivity (1) } \\
\left(\mathrm{W} / \mathrm{m}^{\circ} \mathrm{C}\right)\end{array}$ \\
\hline Quaternary Sediments & Alluviem & 1 & 1.4 \\
\hline Bauru & Sandstone & 55 & $3.7 \pm 1.0$ \\
\hline Serra Geral $\cdots$ & Basalt & 196 & $2.0 \pm 0.2$ \\
\hline Botucatu & Sandstone & 124 & $3.8 \pm 0.8$ \\
\hline Piramboia & Argillaceous & 10 & $2.7 \pm 0.3$ \\
\hline$\because \quad \vdots$ & Sandstone & & . \\
\hline Rio do Rastro & $\begin{array}{l}\text { Argitlaceous } \\
\text { Sandstone }\end{array}$ & 11 & $3.0 \pm 0.3$ \\
\hline
\end{tabular}

(1) Values of arithmetic mean and standard deviation.
The heat flow density values calculated on the bas cumulative thermal resistance values, aquifer tem, tures and mean annual surface temperatures are giv Table 4. Judging from the general pattern of heat the high value at Bauru is doubtful it most probal a result of errors in the determination of To. For exa a value $220 \mathrm{C}$ for To could bring the heat flow sub tialty down to about $70 \mathrm{~mW} / \mathrm{m}^{2}$. Thus the method $\mathrm{s}$ ceptible to large erros in heat flow determination the temperature difference (Ta-To) is small, or in words, for shallow wells.

A recent compilation of heat flow density values fo Parana basin carried out by Hamza and Eston 198 lows a comparison of heat flow values obtained b aquifer temperature method with the conventional tom-hole temperature and geochemical methods results summarized in Table 5 show that the aquifer perature method is capable of furnishing heat fow sity values comparable to those obtained using co tional or bottom-hole temperature methods. Geod cal method based on silica geothermometer seel

Table 3 - Field temperature data for thirteen wells in the western portions of the state of Sao Paulo, used in the Aquifer Tempes Method (ATM)

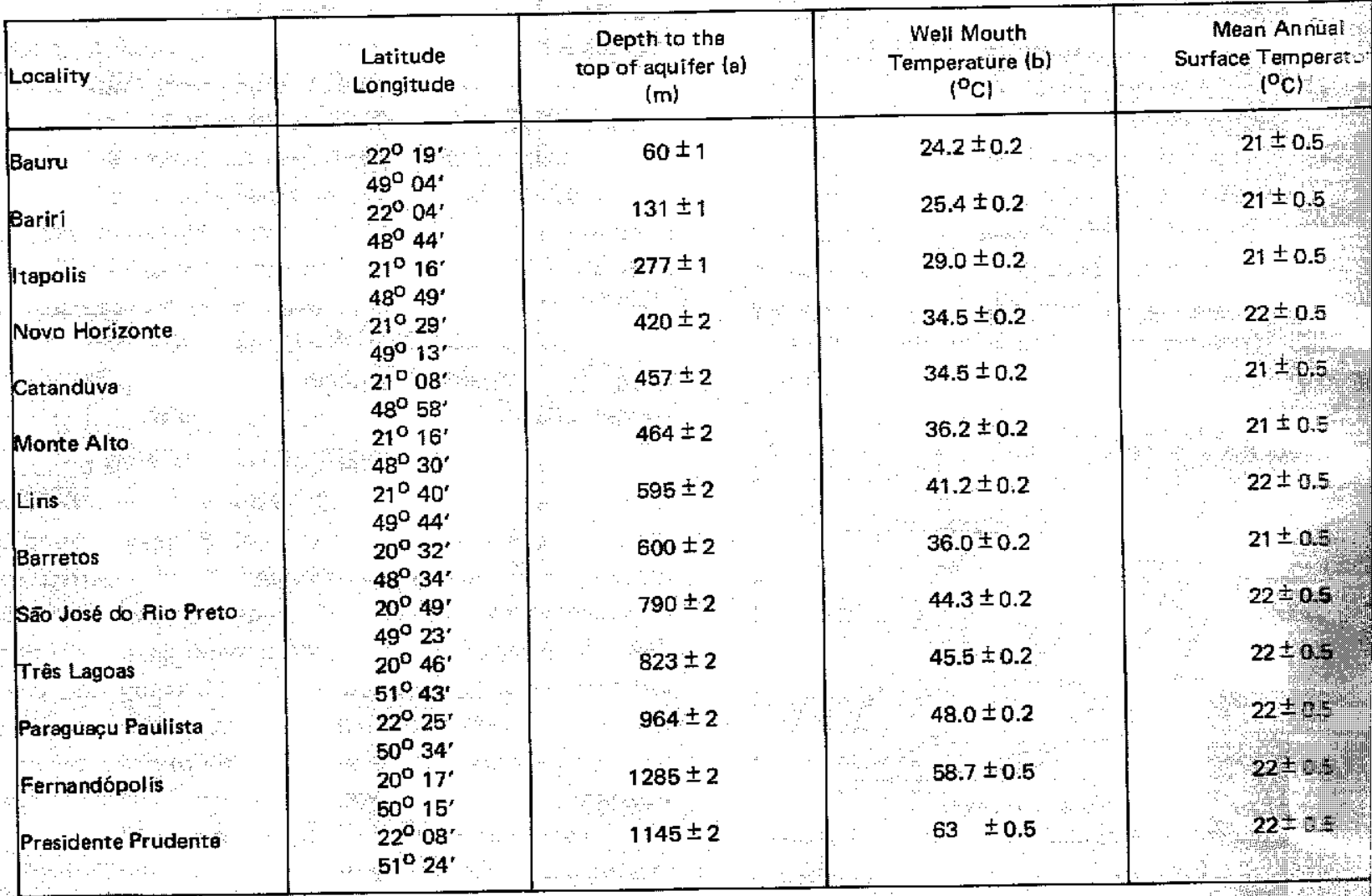

(a) The top of the aquifer corresponds to the interphase between basalt and sandstone. Errors represent estimated values besto 24 th interpretation of driller's log.

(b) Well muth temperatures during pumping tests were measured using mercury thermometers with accuracies of $0,2 \mathrm{C}$ in $\mathrm{t} / \mathrm{t}$, thes to $50^{\circ} \mathrm{C}$ and $0.5^{\circ} \mathrm{C}$ in the interval $50^{\circ} \mathrm{C}$ to $100^{\circ} \mathrm{C}$. 
Table 4 - Heat flow density determinations by the Aquifer Temperature Method for thirteen wells in the western portions of state of São Paulo.

Aquifer temperature is calculed using equation (3) in the text. The values used for specific heat of water and thermal conductivity of wall rocks are $4186 \mathrm{~J} / \mathrm{kg}^{\circ} \mathrm{C}$ and $2 \mathrm{~W} / \mathrm{m}^{\circ} \mathrm{C}$ respectively,

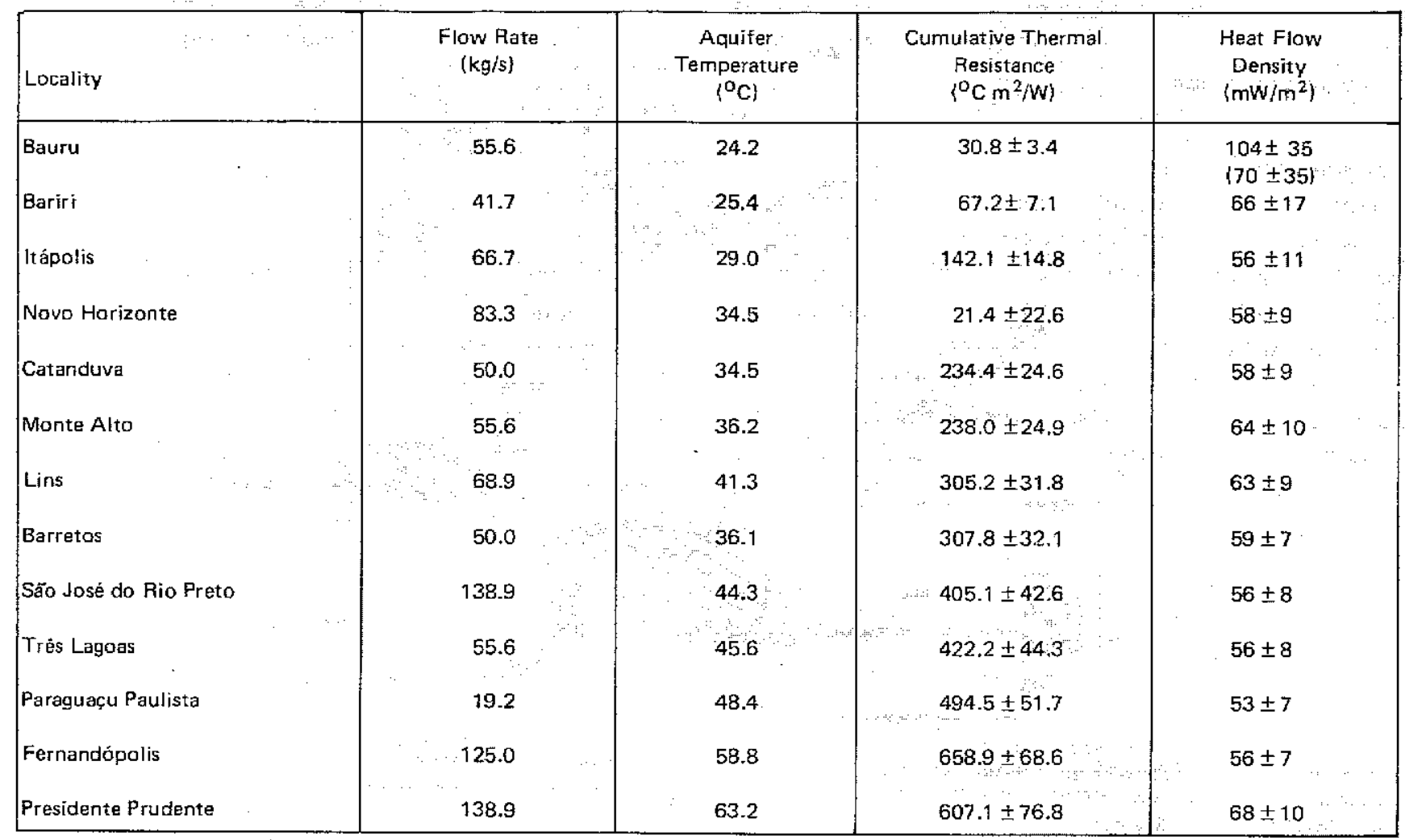

furnish values systematically higher than the others, at least in the present case.

Table 5 - Comparision of terrestrial heat flow density measurements by four different methods in the Parana basin.

\begin{tabular}{|l|c|c|c|}
\hline Method & $\begin{array}{r}\text { Number } \\
\text { of } \\
\text { Measure } \\
\text { ments }\end{array}$ & $\begin{array}{r}\text { Heat Flow Density } \\
\text { (mw/m }{ }^{2}\end{array}$ \\
\hline Conventional & 9 & 59 & 9 \\
Aquifer Temperature & 13 & 62 & 4 \\
Bottom-Hole Temperature & 6 & 58 & 4 \\
Geochemical & & 52 & 10 \\
Quarts only & 10 & $82(1)$ & 10 \\
Chalcedony and Quartz & 10 & $(59)(2)$ & 10 \\
\hline
\end{tabular}

(1) Based on the quartz conductive cooling.

(2) Chalcedony thermometer used for five localities. The problem of when and where to use chalcedony or quartz thermorneter is open to discussion, in the case of low temperature themal waters.

\section{DISCUSSION}

The aquifer temperature method (ATM) can in certain respects be considered as holding an intrinsic advantage over conventional methods in that it makes use of the temperature of a layer with a relatively high thermal inertia and where hydrologically induced thermal disturbances practically comes to a stop while conventional method based on temperature logs in layers overlying the aquifer may lead to values that may not be free from such perturbations. Another main advantage is that it requires a knowledge of only $\mathrm{Ta}$, To and the cumulative thermal resistance, $\mathrm{P}_{\mathrm{i}} \mathrm{Z}_{\mathrm{i}}$.

It is however important to note that the heat flow density as defined by equation (2) is a value that is characteristic of the local geological conditions and may not always provide an accurate estimate of heat flow from deeper layers. Significant departures from background flow may occur under conditions such as low water storage capacity of the aquifer, high water leakage rates, steep dipping strata and low background heat flow. Such conditions usually occur however while dealing with 


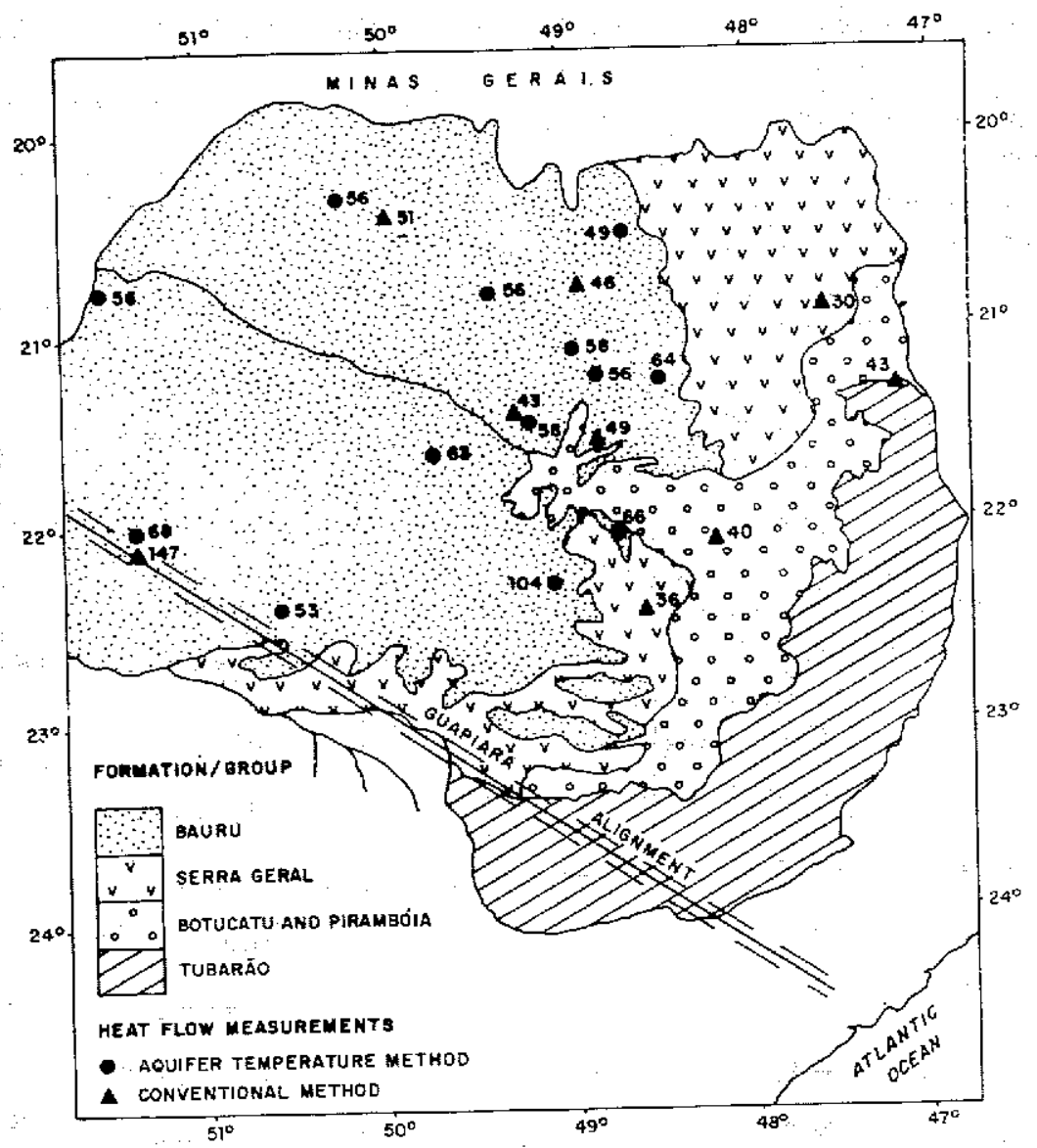

Figure 5 - Simplified geologic map of western part of the State of São Paulo showing locations of heat flow measurements by Aquifer Temperature and Conventional Methods. Heat Flow data by conventional method are taken from the uncompleted thesis work of one of theauthors (J. Santos).

shallow unconfined aquifers. On the other hand it must be remembered that spatial dimensions and time scales associated with groundwater systems are comparable to the regional variability in heat flow and separation of the two effects may easily turn out to be a complicated task.

At this point it is perhaps worth pointing out that though downhole temperature logs are quite valuable in determining conductive geothermal gradient, the linearity in temperature profiles is not always a guarantee that the measured gradient is free of hydrological disturbances either in layers intersected by the borehole or in deeper ones. Lewis and Beck (1977) recognized this problem and cautions against the validity of apparently "good-looking" heat flow values based on measurements in single boreholes. They recommended detailed measurements in a large number of closely spaced boreholes as one way of overcoming the problem, but this solution may not atways be practical due to the sparsity of available boreholes.
The ATM though similar to the bottom temperature technique has some inherent advan over the latter, the main ones being wider regional sentation and access to detailed sampling facilitus thermal conductivity measurements. Since the mi requires only a relatively good thermal conductivit boratory the initial investment in starting a heat flc? gram can be kept to a minimum, a factor worth mo ning in connection with institutions in developing tries. Though we have made use of divided-bar an tus for thermal conductivity measurements it is a sible to adapt OTM (Quick Thermal Conductivity) type devices for rapid measurements of thermal ca tivities of samples in the form of chips or powder,

The present method (ATM) is mainly inte? provide a rapid coverage of terrestrial heat flow distribution in "frontier" areas where conventiont thods may not be practical (ex. presence of put equipments installed in water wells) or possible 
of proper logging equipments). On the other hand the intrinsic advantage of ATM over conventional methods may be exploited for determining deep basal heat flow as well as for evaluating the local variability in heat flow that is related to subsurface fluid circulation pattern.

\section{ACKNOWLEDGMENTS}

Financial support for the field and laboratory studies reported in the present work was provided by Conselho Nacional e Desenvolvimento Cientifico e Tecnológico (CNPq) through research grants . .... . $2222.1154 / 78$ e $40.2735 / 79$ and $40.1248 / 80$. One of us $(J$.
Santos) acknowledge the study leave granted by the Universidade Federal do Rio Grande do Norte during 1978-80 for the execution of the project and CAPES for a research scholarship. The computational expenses were met with the aid of an operating grant awarded to A.E.. Beck by the National Sciences and Engineering Research Council of Canada.

Julia P. Leme (IAG/USP) provided considerable assistance in sample preparation and laboratory measurements of thermal conductivity. We are thankful to our colleagues Sergio M. Eston, Tilson Baltazar da Costa, Tereza Higashi and Suzzanne J. Hurter of IAG/USP for stimulating discussions on the present work as well as for permission to make use of unpublished data from their thesis works. We are indebted to A.E. Beck, E.A. Lubimova and J.H. Sass for critical comments on an earlier draft version of this manuscript.

\section{REFERENCES}

BIRCH, F. - 1947 - Temperature and heat flow in a well near Colorado Springs. Am. 3.Sci., 245: 733-753.

BOLDITZAR, T. - 1958 - The distribution of temperature in flowing wells. Am. J.Sci., 256 : 294.298.

BREDEHOEFT, J.D. \& PAPADOPULOS, I.S. - 1965 -Rates of vertical groundwater movement estimated from the earth's thermal profile. Water Resour. Res.; 1 : 325-328.

BULLARD, E.C. - 1939 - Heat Flow in South Africa Proc. Royal Soc. London, A. 173 : 474-502.

CARVALHO, H.S. \& VACQUIER, V. - 1977 - Method for determining terrestrial heat flow in oil fields. Geophysics, 42 : 584 593.

DAEE - 1981 - Estudo de Águas Subterrâneas, Região Administrativa 10 e 11, Presidente Prudente e Marilia Vol. 1 Texto, Report prepared for Departamento de Águas e Energia Elétrica by Geopesquisadora Brasileira Ltda. and Tahal Consulting Engineers Ltd.

EVANS, T.R. - 1977 - Thermal Properties of North Sea rocks. The Log Analyst, March-Aprll, 3-12.

EVERETT, J.D. - 1882 - Rept. Brit. Assoc. for 1882, 72-90

HAMZA, V.M. \& ESTON, S.M. - 1982 - Assessment of geothermal resources of Brazil - 1981. Zentralblatt für Geol. Pallāont., $1=128-155$.

LEWIS, T.J. \& BECK, A.E. - 1977 - Analysis of heat flow data Detailed observations in many holes in a small area. Toctonophysics, 41 : 41-60.
HURTER, S.J. - 1984 - Termometria quimiça aplicada à exploração de depósitos geotermais; in Anais do Simpósio Bra. sileiro sobre técnicas exploratórias aplicadas à Geologia, Salvador, p.78-97.

MANSURE, A.J. \& REITER, M. - 1979 - A vertical groundwater movement correction for heat flow. J. Geophys. Res, 84 : $3490-3496$.

PEREIRA, R.V. - 1969 - Atlas Climatológico do Brasil (Reedição de Mapas Selecionados), Publicaçāo do Ministério da Agricultura, ECEPLAN, Rio de Janeiro.

SASS, J.H., LACHENBRUCH, A.H. \& MUNROE, R.J. - 1971 Thermal conductivity of rocks from measurements on fragments and its application to heat-flow determinations J. Geophys. Res., $76: 3391-3401$.

STALLMAN, R.W. - 1960 - Computation of groundwater velocity from temperature data. U.S. Geal. Survey Water Supply Paper, 1544-H: 36-46.

SWANBERG, C.A. \& MORGAN, P. - 1978 - The linear relation between temperature based on the silica content of ground water and regional heat flow: A new heat flow map of the United States. Pure Appl. Geophys., 117 : 227-241.

TRUESDELL, A.H., NATHENSON, M. \& RYE, R.O. - 1977 - The effects of subsurface boilling and dilution on the isotopic composition of Yellowstone thermal waters. J. Geophys. Res., 82 : 3694-3704. 